\title{
Evaluation of extruded corn breakfast cereal enriched with whole peach palm (Bactris gasipaes, Kunth) Flour
}

\author{
Ivone Lima SANTOS ${ }^{1}$, Marcio SCHMIELE² ${ }^{2}$ Jaime Paiva Lopes AGUIAR ${ }^{3}$, Caroline Joy STEEL ${ }^{4}$, \\ Edson Pablo SILVA ${ }^{3}$, Francisca das Chagas do Amaral SOUZA ${ }^{3 *}$ (D)
}

\begin{abstract}
The present study aimed to develop extruded corn breakfast cereal enriched with whole peach palm flour. A $2^{2}$ central composite rotatable design was used, and the cereal was processed in a ZKS-30 co-rotational twin-screw extruder (Werner and Pfleiderer), followed by its physicochemical, technological and microbiological characterization. The technological analysis revealed higher expansion and lower hardness as well as adequate lightness and water-absorption and water-solubility indices of the breakfast cereal at low moisture and intermediate peach palm flour contents. Moreover, $3.84 \%$ moisture, $0.63 \%$ ash, $6.09 \%$ protein, $0.39 \%$ lipids, $85.94 \%$ carbohydrates, $3.11 \%$ fiber and $246 \mathrm{RE}$ of total carotenoids were found in the physicochemical analysis, and the microbiological parameters were in accordance with the Brazilian legislation (Resolution RDC 12/01). These results show that extruded corn breakfast cereal partially substituted with peach palm flour is an alternative product with good characteristics and market potential. The most recommended operational conditions to obtain products with good technological characteristics were a peach palm flour concentration of $25 \%$ and feed moisture of $16.2 \%$.
\end{abstract}

Keywords: extrusion; new products; peach palm tree; substitution; characteristics.

Practical Application: The processing of an Amazonian fruit was studied to add value to breakfast cereals. The peach palm flour presented a high content of bioavailable carotenoids, as well as carbohydrates, proteins and lipids, showing with an important nutritional source.

\section{Introduction}

The genus Bactris constitutes one of the most diversified palm groups in the New World, encompassing around 92 species, and its greatest diversity is found in the Amazon Basin, where at least 30 species are known to occur. The peach palm tree (Bactris gasipaes, Kunth), from the palm family, is a multi-stem plant native to the wet tropics of the Amazon. It produces edible fruits, the flavor of which is highly appreciated in the region, and is definitely integrated into the eating habits of the Amazonian population (Nazário et al., 2017). The increasing demand of the consumer market for new products stimulates the use of regional raw materials.

The preparation of peach palm flour (PF) is a way to avoid saturating the raw fruits market and to diversify the demand for peach palm (Oliveira \& Marinho, 2010). The fruit peel can also be processed to enrich the peach palm flour. In addition to avoiding waste, the inclusion of fruit peel increases the amount of fiber in the product. According to Nair et al. (2010), fibers comprise a group of components that are considered to be functional. Moreover, the inclusion of fruit peel increases the nutritional quality of peach palm by increasing the bioavailable beta-carotene. According to Silva et al. (2017) the potential market for the fruit is much larger because of the nutritional, sensory properties and visual qualities, which can be explored for creating new products and markets.

The consumption of breakfast cereals has increased considerably in recent years because products that are quickly prepared are in demand due to the lack of time characteristic of modern life (Bolanho et al., 2014). These products can be produced through thermoplastic extrusion. According to Fellows (2006), thermoplastic extrusion is a high-temperature-short-time (HTST) thermal treatment. The basic principle of this process is the conversion of a solid material (usually in the form of flour) into a fluid melt by applying heat and shear, and the molten material is extruded through a die (Hirth et al., 2014). The incorporation of dehydrated fruits into snacks and breakfast cereals can improve the nutritional quality and attractiveness of these foods. The fruits and extracts are rich in bioactive components, in addition to providing an acceptable sensory properties quality (Potter et al., 2013).

Therefore, the present study aimed to develop extruded corn breakfast cereal enriched with whole peach palm flour.

${ }^{1}$ Programa de Pós-graduação em Ciência dos Alimentos, Universidade Federal do Amazonas - UFAM, Manaus, AM, Brasil

${ }^{2}$ Instituto de Ciência e Tecnologia, Universidade Federal do Vale Jequitinhonha e Mucuri - UFVJM, Diamantina, MG, Brasil

${ }^{3}$ Coordenação de Sociedade Ambiente e Saúde - COSAS, Laboratório de Fisico-química de Alimentos - LFQA, Instituto Nacional de Pesquisas na Amazônia - INPA, Manaus, AM, Brasil

${ }^{4}$ Departamento de Tecnologia de Alimentos, Escola de Engenharia de Alimentos, Universidade de Campinas - UNICAMP, Campinas, SP, Brasil

${ }^{*}$ Corresponding author: francisca.souza@inpa.gov.br 


\section{Materials and methods}

\subsection{Materials}

The following raw materials were used in this study: corn flour, provided by Mina Mercantil (Guaíra, SP, Brazil); and peach palm flour processed with utilization of the whole fruit. The peach palm flour was obtained by dehydration at $60^{\circ} \mathrm{C} / 48 \mathrm{~h}$ and yours content evaluated in the Laboratory of Physical Chemistry of Food (LFQA) - INPA, (Manaus, AM, Brazil). The chemical composition of commercial corn flour provide by Mina Mercantil, showed the values respectively of $12.25 \%$ moisture, $6.31 \%$ protein, $1.1 \%$ fat, $77.18 \%$ for carbohydrates, $0.35 \%$ ash and $2.74 \%$ of fibers.

\subsection{Methods}

\section{Processing of the breakfast cereals}

The central composite rotatable design (Table 1) was used to analyze the effects of formulation (peach palm flour concentration) and an important thermoplastic extrusion process parameter in the technological properties of extruded products. Processing was carried out by setting the temperature within the four extrusion zones $70^{\circ} \mathrm{C}, 100^{\circ} \mathrm{C}, 130{ }^{\circ} \mathrm{C}$ and $150^{\circ} \mathrm{C}$ for zones 1 through 4 , respectively. These variables were kept constant to guarantee the stability of beta-carotene, according to Cozzolino \& Cominetti (2013). The effects of the raw material moisture content 15-23\% and peach palm flour concentration $0-50 \%$ on the expansion index (EI), specific volume (SV), compression force, instrumental color $\mathrm{L}^{*}, \mathrm{a}^{*}$ and $\mathrm{b}^{*}$ parameters, water-absorption index (WAI) and water-solubility index (WSI) were analyzed.

The samples were conditioned by adding distilled water with a burette and using a planetary mixer, model K45SS (Kitchenaid, St. Joseph, USA). To obtain uniform moisture content, the conditioned material was placed in high density metallized polyethylene bags and stored for $24 \mathrm{~h}$ at room temperature before processing.
The processing was performed in a co-rotable twin-screw extruder, model ZKS-30 (Werner and Pfleiderer, Ramsey, USA), with screw speed at $180 \mathrm{rpm}$; feed rate at $11.88 \mathrm{~kg} \cdot \mathrm{h}^{-1}$; and a circular die with 2 holes of $2.8 \mathrm{~mm}$ of opening. After extrusion, the extrudates were dried in a 2068 continuous rotary dryer (Inbramaq, Ribeirão Preto, BRA) at $125^{\circ} \mathrm{C}$ until the moisture content was lower than $7 \%$. They were then packed in laminated flexible packaging and stored at room temperature $\left( \pm 25^{\circ} \mathrm{C}\right)$ until analyses for determining the optimal point through characterization of the technological properties.

\section{Technological characterization of the breakfast cereals}

The technological characterization of the breakfast cereals included the determination of the expansion index (EI), which is the ratio between the diameter of the extrudates and the diameter of the die. Diameter measurements were made with a Craftsman caliper and the calculations according to the methodology proposed by Mercier et al. (1998). Specific volume (SV) was determined according to Meng et al. (2010), determining volume through the volumetric displacement of millet seeds. Texture was evaluated using a TA-XT2i - Texture Analyser (Stable Micro Systems, Haslemere, GRA), measuring compression force, with a $25-\mathrm{kg}$ load cell, equipped with the Texture Expert ${ }^{\circ}$ software to analyze the data according to Chang et al. (2001). A Warner Bratzler (HDP/WBV) probe was used and the test parameters were: pre-test speed $(4.0 \mathrm{~mm} / \mathrm{s})$, test speed $(1.0 \mathrm{~mm} / \mathrm{s})$, and post-test speed $(5.0 \mathrm{~mm} / \mathrm{s})$; and distance to rupture $(1.0 \mathrm{~mm})$. For instrumental color, a Mini Scan XE 45/0-L spectrophotometer (Hunterlab, Reston, USA) was used. The equipment was calibrated with a white and black plate with illuminant D65 and observer angle at $10^{\circ}$. Water absorption index (WAI) and water solubility index (WSI) were determined according to Anderson et al. (1969).

Table 1. Technological properties of the extrudates.

\begin{tabular}{|c|c|c|c|c|c|c|c|c|c|c|c|c|}
\hline \multirow[b]{2}{*}{ Trial } & \multicolumn{2}{|c|}{$\mathrm{X}_{1}$} & \multicolumn{2}{|c|}{$\mathrm{X}_{2}$} & \multicolumn{8}{|c|}{ Technological properties } \\
\hline & $\mathrm{Cv}$ & $\mathrm{Rv}$ & $\mathrm{Cv}$ & $\mathrm{Rv}$ & $\begin{array}{l}\text { Expansion } \\
\text { index }\end{array}$ & $\begin{array}{l}\text { Specific } \\
\text { volume } \\
\left(\mathrm{mL} \cdot \mathrm{g}^{-1}\right)\end{array}$ & $\begin{array}{l}\text { Compression } \\
\text { force }(\mathrm{N})\end{array}$ & $L^{*}$ & $a^{*}$ & $b^{*}$ & $\begin{array}{c}\text { WSI } \\
\left(\mathrm{g} .100 \mathrm{~g}^{-1}\right)\end{array}$ & $\begin{array}{l}\text { WAI (g of gel/100g } \\
\text { of sample) }\end{array}$ \\
\hline 2 & +1 & 21.8 & -1 & 7.3 & 3.79 & 60.00 & 10.23 & 61.31 & 5.81 & 42.46 & 30.59 & 863.36 \\
\hline 3 & -1 & 16.2 & +1 & 42.7 & 3.38 & 55.67 & 6.07 & 57.16 & 10.34 & 41.92 & 12.86 & 628.78 \\
\hline 6 & $+a$ & 23 & 0 & 25 & 2.43 & 48.67 & 12.38 & 57.42 & 9.38 & 44.57 & 14.94 & 728.87 \\
\hline 7 & 0 & 19 & $-\alpha$ & 0 & 3.46 & 67.00 & 9.01 & 60.17 & 6.21 & 43.57 & 35.00 & 881.30 \\
\hline 8 & 0 & 19 & $+a$ & 50 & 2.60 & 50.67 & 9.46 & 54.73 & 11.89 & 43.32 & 10.31 & 567.85 \\
\hline 9 & 0 & 19 & 0 & 25 & 3.68 & 57.33 & 10.04 & 57.27 & 8.59 & 40.32 & 20.78 & 818.34 \\
\hline 10 & 0 & 19 & 0 & 25 & 3.69 & 58.67 & 9.44 & 56.24 & 8.96 & 44.14 & 19.00 & 815.84 \\
\hline
\end{tabular}

$\mathrm{X}_{1}$ : feed moisture (\%); $\mathrm{X}_{2}$ : peach palm flour concentration (\%); Cv: coded value; Rv: real value; adial expansion index $=$ Expansion index; $(\mathrm{N})$ newton force; $\mathrm{L}^{\star}$ : lightness, $\mathrm{a}^{\star}$ coloration value; $\mathrm{b}^{*}$ coloration value; WAI: water-absorption index and WSI: water-solubility index. 


\section{Chemical characterization of the optimal point and control sample}

The optimal point was elaborated in true triplicate. A control sample (only corn flour) was produced in the same conditions. The chemical composition (moisture, lipids, ash, protein and total dietary fiber) of the optimal cereal and control sample was determined according the AACC methods (American Association of Cereal Chemists, 2010).

Iron, copper, calcium, magnesium, zinc, manganese, sodium and potassium were determined by atomic absorption spectrometry, as defined by the Instituto Adolfo Lutz (2008), where sample digestion was carried out by microwaves in a MARS - Xpress CEM Corporation, MD - 2591 digester, mineralization of organic matter with concentrated nitric acid, followed by cooling and dilution with deionized water. Readings were carried out directly in the diluted solutions in an atomic absorption spectrophotometer (Spectra AA, model 220 FS, Varian, 2000), with specific lamps according to the supplier's manual. For the control of the analyses, certified reference materials (Peach leaves (NIST - SEM 1547)) were used.

The total carotenoids were determined by extraction with hexane, isopropyl alcohol and distilled water at a ratio of 1:3:1, in which the cereal was maintained until separation occurred. The extracted orange color was quantified with a spectrophotometer at $450 \mathrm{~nm}$, according to the methodology described by AOAC (Association of Official Agricultural Chemists, 2010).

\section{Water activity}

The water activity (Aw) was performed in each of the trials and the optimum point, in triplicates, using the AQUALAB - Dew Point apparatus, Water Activity Meter 4TEV.

\section{Microbiological characterization of the optimal cereal}

For the microbiological analyses of the optimal cereal, the samples were analyzed according to the standards for the food category (extruded breakfast cereals) presented in Resolution RDC 12/01 by the National Health Surveillance Agency (Agência Nacional de Vigilância Sanitária - ANVISA) (Brasil, 2001). The analytical methodologies adopted followed the Manual of the Methods of Food Microbiological Analysis the methodology proposed by ICMSF (International Commission on Microbiological Specifications for Foods, 1983), and the following microorganisms were analyzed: total and thermotolerant coliforms, Escherichia coli, Bacillus cereus, yeasts and molds.

\subsection{Statistical analysis and choice of the optimal point}

The results were evaluated by the Surface Response Methodology at $10 \%$ significance level. The minimum regression coefficient $\left(\mathrm{R}^{2}\right)$ adopted was 0.80 for the ANOVA to ensure the validity of the predictions provided by the mathematical model (in codified levels) and for the development of the contour plots. The choice of the optimal point was performed according to Derringer \& Suich (1980), using the desirability function.

\section{Results and discussion}

The characterization for peach palm flours showing the dates respectively, $4.45 \%$ moisture, $4.31 \%$ protein, $1.17 \%$ fat, $77.18 \%$ carbohydrates, $0.35 \%$ ash and $13.21 \%$ fibers. As results of the food production flour, observed a significant content of the food fiber variable, indicating your importance in the food formulations. Similar values for food fiber content were found by Tavares et al. (2016) when studies the stability of gluten free sweet biscuit elaborated with rice bran, broken rice and okara. For the results from the evaluation of the technological properties of the extrudates, including the expansion index, specific volume, compression force, instrumental color, water solubility index and water absorption index are presented in Table 1. The contour plots and mathematical models generated using the Response Surface Methodology can be seen in Figure 1 and Table 2, respectively.

Regarding the radial expansion index, the extrudates showed values between 2.43 and 4.07. By increasing the peach palm flour and feed moisture of the blend within the studied ranges, the EI decreased, and the greatest radial expansion was obtained with low moisture and low peach palm flour contents in the blend (Figure 1a). The mathematical model explains $80.51 \%$ of the experimental values by the ANOVA (Table 2 ).

Water acts as a plasticizer during the extrusion process, lowering the water vapor pressure formed in the extruder barrel, reducing the EI (Oliveira et al., 2015). The influence of the peach palm flour on the EI can be explained due to its fat and fiber contents (Masuzaki et al., 2015), and also because in the process used to obtain the flour, the fruits were first cooked, resulting in a pre-gelatinization of the starch. Pre-gelatinized

Table 2. Mathematical models obtained for the technological parameters and validation.

\begin{tabular}{|c|c|c|c|c|c|c|}
\hline Dependent variable & Mathematical model & $\mathrm{R}^{2}(\%)$ & $\mathrm{p}$-value & $\begin{array}{l}\text { Predicted } \\
\text { value }\end{array}$ & $\begin{array}{l}\text { Experimental } \\
\text { value }\end{array}$ & $\begin{array}{c}\text { Relative } \\
\text { deviation } \\
(\%)\end{array}$ \\
\hline Expansion index & $3.68-0.31 \mathrm{x}_{1}-0.38 \mathrm{x}_{2}-0.24 \mathrm{x}_{1}^{2}-0.20 \mathrm{x}_{2}^{2}$ & 80.51 & 0.012 & 3.26 & $3.42 \pm 0.11$ & 4.68 \\
\hline Specific volume (mL.g $\left.{ }^{-1}\right)$ & $56.19-13.58 x_{1}-9.36 x_{2}+5.70 x_{1}^{2}$ & 88.80 & $<0,001$ & 69.30 & $72.54 \pm 0.97$ & 4.47 \\
\hline Compression force $(\mathrm{N})$ & $10.14+2.46 \mathrm{x}_{1}+2.69 \mathrm{x}_{1} \mathrm{x}_{2}$ & 88.13 & $<0.001$ & 9.54 & $8.89 \pm 0.21$ & 6.81 \\
\hline$L^{*}$ & $57.50-1.48 x_{1}-2.71 x_{2}+0.97 x_{1}^{2}$ & 86.70 & 0.001 & 60.56 & $64.01 \pm 2.57$ & 5.39 \\
\hline$a^{*}$ & $8.84+0.37 \mathrm{x}_{1}+2.30 \mathrm{x}_{2}+0.76 \mathrm{x}_{1} \mathrm{x}_{2}$ & 98.00 & $<0.001$ & 5.99 & $6.12 \pm 0.25$ & 2.12 \\
\hline $\begin{array}{l}\text { Water absorption index } \\
\text { ( } \mathrm{g} \text { of gel/100g of sample) }\end{array}$ & $795.27-23.87 x_{1}-126.88 x_{2}-17.95 x_{1}^{2}-36.08 x_{2}^{2}$ & 97.04 & $<0.001$ & 885.70 & $823.54 \pm 12.89$ & 7.55 \\
\hline
\end{tabular}

(N) newton force; $L^{\star}$ : lightness, $a^{*}$ coloration value. 

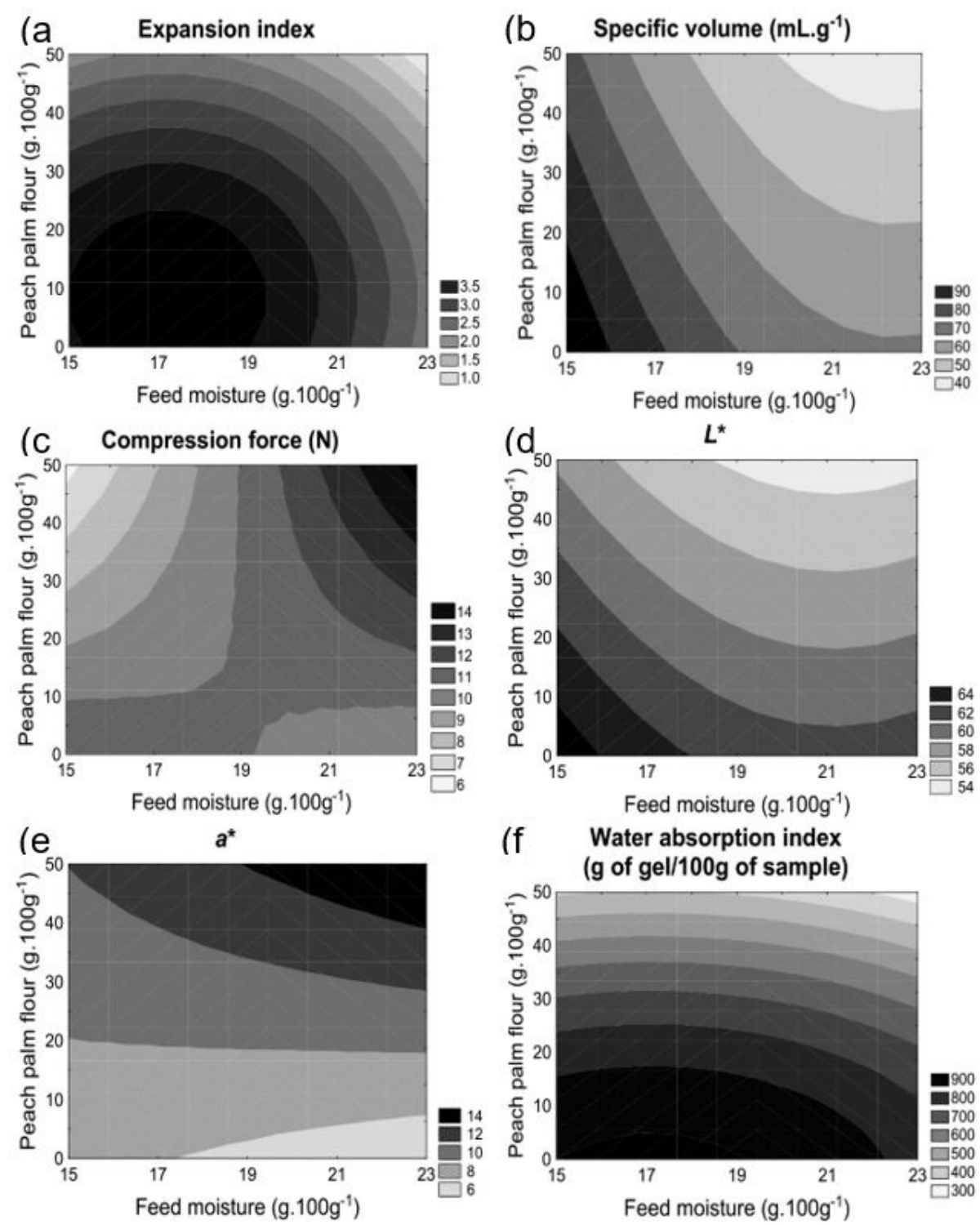

Figure 1. Contour plots for dependent variables with statistical significance $(P \leq 0.10)$.

starch reduces mechanical shear in the extrusion process and promotes a significant impact on EI.

The specific volume of the extrudates ranged between 33.67 and $95 \mathrm{~mL} \cdot \mathrm{g}^{-1}$ and was highly influenced by the feed moisture, more than peach palm flour. The mathematical model (Table 1) explains $88.80 \%$ of the experimental values. The increase in EI with greater gas bubbles resulted in a product with higher specific volume.

Regarding compression force, the extrudates had values between 6.07 and $17.03 \mathrm{~N}$ as minimum and maximum values, respectively, and the results were explained by $88.13 \%$ through the mathematical model (Table 2). According to Anton \& Luciano (2007), the acceptance of expanded products by the consumer is highly influenced by the texture of the product. Higher values of EI and specific volume usually result in an extrudate with lower compression force. Feed moisture showed a greater effect on the texture characteristics (Figure 1c). The extruded cereals produced with lower feed moisture resulted in lower hardness values as a consequence of greater expansion. Even with lower influence, the use of peach palm flour promoted a texture with lower compression force, probably due to the fragile gas cells produced, with weak cell walls. Onwulata et al. (2001), highlight that a reduction of expansion and an increase in hardness are characteristic of products with added fiber. However, Ferreira et al. (2012) found an opposite effect of fibers on compression force. Wang et al. (2017), also found that moisture was the most significant factor affecting the hardness of expanded extruded rice cereals and that an increase in the moisture content resulted in an increase in compression force.

For the coloration results the lightness $\left(L^{*}\right)$ of the raw materials, corn flour exhibited a lighter color with a higher $L^{*}$ value (87.43) and a greater tendency towards yellowness than the peach palm flour, which presented a lower $L^{*}$ value (74.27), with a greater tendency towards an orange color. The use of peach 
palm flour showed a higher effect (Figure 1d). The increase in $L^{*}$ values as a result of the lower feed moisture can be explained by the higher EI, where the greater gas bubbles reduce the concentration of the raw material pigments.

The parameter $a^{*}$ was lower with the increase in feed moisture and decrease in the levels of peach palm flour (Figure 1e), and ranged between 5.81 and 12.49 (Table 1). The mathematical model (Table 2) explains $98.00 \%$ of the experimental data. The effect of the feed moisture could be the same as for $L^{\star}$ values, and the influence of peach palm flour can be explained due to the higher $a^{\star}$ value for this kind of flour (11.23) in relation to corn flour (7.48). The independent variables did not show significant influence on $b^{*}$ values.

The data obtained for WAI can be explained by $97.04 \%$ through the mathematical model (Table 2). It can be observed in Figure 1e that the peach palm flour showed a higher influence than feed moisture on this parameter. WAI is a result of the hydrogen bonds formed with the exposure of starch hydroxyl groups by the extrusion process. With the increase in peach palm flour, the starch content was diluted in the sample, resulting in lower WAI levels. The increase in feed moisture results in a greater plasticizing effect in the extruder barrel, resulting in lower dextrinization and lower hydroxyl groups exposure.

The optimal point was chosen in order to use at least $25 \mathrm{~g} .100 \mathrm{~g}^{-1}$ of peach palm flour, obtaining the maximum expansion index and specific volume and the minimum compression force. For the desirability function, the level of feed moisture was kept in the range studied, also as the results for $L^{*}, \mathrm{a}^{*}$ and WAI. So, the optimal point was defined by the use of $25 \mathrm{~g} .100 \mathrm{~g} \mathrm{~g}^{-1}$ of peach palm flour and $16.2 \mathrm{~g} .100 \mathrm{~g}^{-1}$ of feed moisture, which corresponded to 0 and -1 , in coded levels, resulting in a desirability of 0.71 , as shown in Table 2. All the mathematical models were validated, because the relative deviation was lower than $10 \%$.

The chemical composition of the cereal considered to be the optimal point (Table 3), the values obtained were similar to those found by Leoro et al. (2009), who developed a breakfast cereal made with passion fruit flour containing 3.74\% moisture, $8.91 \%$ protein, $0.54 \%$ lipids, $1.45 \%$ ashes and $85.37 \%$ carbohydrates.

The values of the cereal considered to be the optimal point approached those of the control cereal, with minimal variations. Only the fiber $(0.67 \%)$ and moisture $(5.74 \%)$ contents had greater variations in the cereal partially substituted with pupunha flour. Although the moisture content is above that of the cereal considered as optimal point, this value is still satisfactory because the desired moisture value is lower than $7 \%$ and was controlled by drying the cereal. The addition of whole pupunha flour to the cereal led to the expected results in the incorporation of fiber $(3.11 \%)$, which can be observed in the comparison with the control (0.67\%).

The minerals in the optimal point and control cereals are presented in Figure 2. This information indicates that the amounts of macro- and micro minerals in the cereal considered

Table 3. Proximate composition of the optimal point breakfast cereal enriched with whole peach palm (Bactris gasipaes, Kunth) flour compared to the control and to a commercial product.

\begin{tabular}{lccc}
\hline \multicolumn{1}{c}{ Component } & Optimal point & Control & Commercial \\
\hline Moisture (\%) & $3.84^{\mathrm{b}} \pm 0.54$ & $5.74^{\mathrm{a}} \pm 0.45$ & - \\
Ash (\%) & $0.63^{\mathrm{a}} \pm 0.02$ & $0.42^{\mathrm{a}} \pm 0.04$ & - \\
Proteins (\%) & $6.09^{\mathrm{a}} \pm 0.73$ & $6.71^{\mathrm{a}} \pm 0.81$ & $1.2^{\mathrm{b}} \pm 0.11$ \\
Lipids (\%) & $0.39^{\mathrm{a}} \pm 0.02$ & $0.08^{\mathrm{b}} \pm 0.01$ & -- \\
Digestible carbohydrates (\%) & $85.94^{\mathrm{b}} \pm 2.21$ & $86.38^{\mathrm{a}} \pm 2.23$ & $26^{\mathrm{c}} \pm 1.23$ \\
Total dietary fiber (\%) & $3.11^{\mathrm{a}} \pm 0.54$ & $0.67^{\mathrm{b}} \pm 0.01$ & 0 \\
Total carotenoids & $246^{\mathrm{a}} \pm 3.25 \mathrm{RE}$ & $16^{\mathrm{b}} \pm 3.36 \mathrm{RE}$ & $144^{\mathrm{b}} \pm 2.20 \mathrm{RE}$ \\
\hline
\end{tabular}

Optimal point: $25 \%$ pupunha flour, $75 \%$ corn flour, $16.2 \%$ feed moisture; Control: 100\% corn flour, $16.2 \%$ feed moisture; RE: Retinol equivalents; Means followed by the same letter in the line does not differ $(\mathrm{p}<0.1)$.
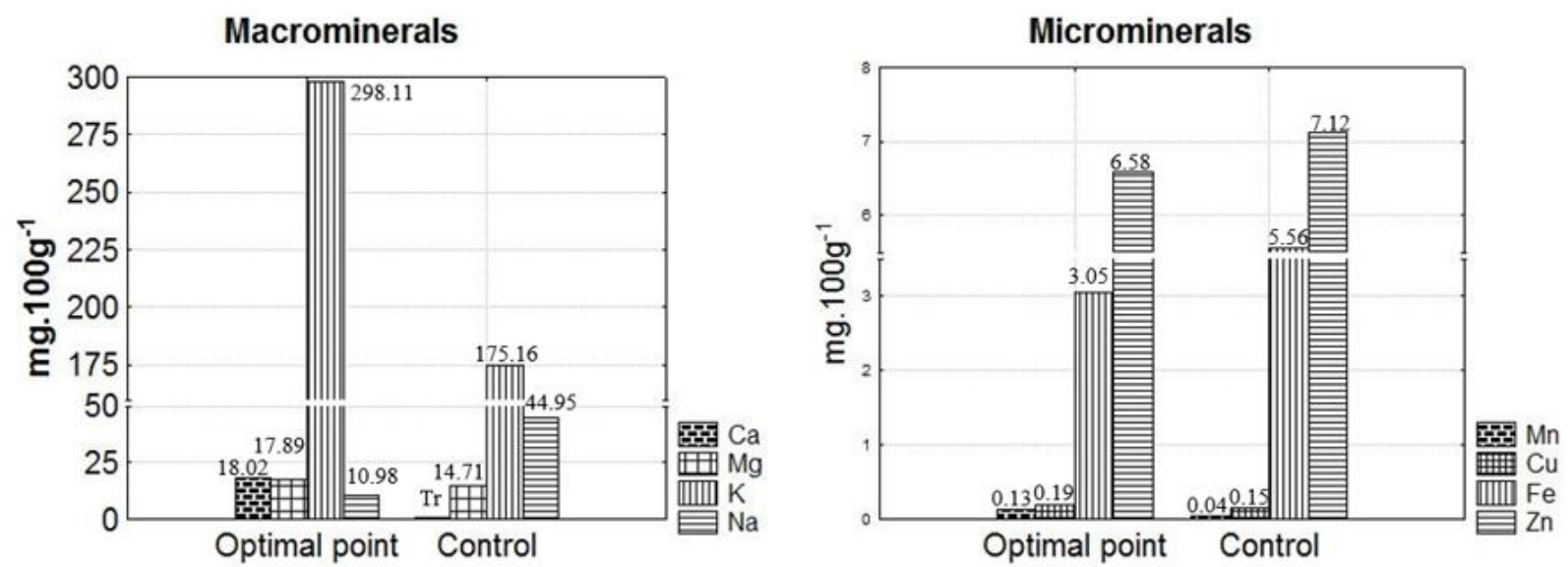

Figure 2. Macrominerals and microminerals content for optimal point and control sample. Means followed by the same letter does not differ $(\mathrm{p}<0.1$ ) 
as the optimal point were higher than those in the control cereal. However, the value for the $\mathrm{Na}$ macromineral remained lower than in the control, which is a desirable result considering that a high Na content in industrialized products is harmful to health.

The micromineral Fe also exhibited lower but similar values to those of the control, a result that can be explained by the enrichment of corn flour with iron, in accordance with resolution RDC 344/02 (Brasil, 2002). Nevertheless, in the cereal considered as the optimal oint, the mineral $\mathrm{K}$ was present at a significant amount (298.11 mg.100 g $\mathrm{g}^{-1}$ when compared to the remaining minerals).

The caloric value of a 30-g portion of the pupunha-enriched cereal considered as the optimal point is $111.52 \mathrm{kcal}$, calculated from the proximate composition (Table 3 ). This value is similar to the caloric value of breakfast cereals available in the market, which varies from 108.8 to $111.34 \mathrm{kcal} 30 \mathrm{~g}^{-1}$. The macronutrients of the cereal considered as the optimal point also presented values similar to the commercial breakfast cereals, with carbohydrate values ranging from 23 to $26 \mathrm{~g}$, protein values from 1.2 to $2.16 \mathrm{~g}$ and lipids from 0 to $1.4 \mathrm{~g}$ (for the $30 \mathrm{~g}$ portion). However, the advantage of the cereal containing pupunha flour is in relation to the mineral $\mathrm{K}$, which was present at a satisfactorily high value, and sodium, which was present in a reduced amount compared to industrialized products, in addition to the benefits related to the presence of fibers and carotenoids.

The nutritional information revealed lower levels of minerals in the cereal considered as the optimal point compared to the commercial breakfast cereal brands, for which sodium ranged from $111 \mathrm{mg}$ to $196.5 \mathrm{mg}$, iron ranged from 0.93 to $4.2 \mathrm{mg}$, zinc ranged from 1.3 to $1.7 \mathrm{mg}$, and calcium ranged from 42.9 to $209 \mathrm{mg}$ for the $30-\mathrm{g}$ portion. All of these minerals were present in higher amounts compared to the optimal point cereal that was developed. The higher calcium and vitamin A (RE) values in commercial cereals can be explained by the enrichment of these products with these vitamins and minerals. However, the lower Na value (3.26 mg. $30 \mathrm{~g} \mathrm{~g}^{-1}$ for the optimal point cereal is a desirable result because the excess of sodium in industrialized foods can be harmful to health. Nevertheless, unlike other minerals, K was present at higher levels in the cereal considered as the optimal point, with a significant difference from brand D $24.9 \%$, and therefore, the optimal point cereal can complement the daily requirements for this mineral. The total carotenoid content was lower than the amount in brand A (144 RE), which can be explained by the instability of carotenoids to oxygen and light, both of which affected the processing of the pupunha flour.

The results of the microbiological analyses indicated that neither the cereal considered as the optimal point nor the control cereal presented contaminating microorganisms above the allowed limit for total and thermotolerant coliform levels (0.0 NMP.g-1); both were negative for Escherichia coli and Bacillus cereus, free of molds and yeast and negative for Salmonella sp, thus meeting the standards of the National Health Surveillance Agency (Brasil, 2001). The negative result for microbial growth can be explained by the low water activity in the optimal point (aw $=0.2292)$ and control ( $\mathrm{aw}=0.2464)$ cereals, as well as the high temperatures applied during the process.

\section{Conclusions}

The most recommended operational conditions to obtain products with good technological characteristics were a peach palm flour concentration of $25 \%$ and feed moisture of $16.2 \%$. The results demonstrated that these snacks have desirable characteristics for consumers and a potential for future commercialization.

\section{Acknowledgements}

The authors thank the CAPES and Amazon Research Foundation (FAPEAM - Fundação de Amparo à Pesquisa do Estado do Amazonas) for financial support, Process 062.01725/2014 - PAPAC and 062.00682/2015 Universal.

\section{References}

American Association of Cereal Chemists - AACC. (2010). Approved Methods of Analysis (11th ed.). St. Paul: AACC International.

Anderson, R., Conway, H., Pfeifer, V., \& Griffin, E. L. (1969). Gelatinization of corn grits by roll-and extrusion-cooking. Cereal Science Today, 14(1), 1-4.

Anton, A. A., \& Luciano, F. B. (2007). Instrumental texture evaluation of extruded snacks foods: a review. Food Science and Technology (Campinas), 5(4), 245-251.

Association of Official Agricultural Chemists - AOAC. (2010). Official Methods of the Association of the Agricultural Chemists. Washington: AOAC.

Bolanho, B. C., Danesi, E. D. G., \& Beleia, A. P. (2014). Characterization of flours made from peach palm (Bactris gasipaes Kunth) byproducts s a new food ingrediente. Journal of Food and Nutrition Research, 53(1), 51-59.

Brasil. Agência Nacional Vigilância Sanitária - ANVISA. (2001). Aprova o regulamento técnico sobre padrões microbiológicos para alimentos (Resolução RDC no 12, de 02 de Janeiro de 2001). Diário Oficial [da] República Federativa do Brasil. Retrieved from http:// portal.anvisa.gov.br/wps/wcm/connect/a47bab8047458b909541d 53fbc4c6735/RDC_12_2001.pdf?MOD=AJPERES

Brasil. Agência Nacional Vigilância Sanitária - ANVISA. (2002, December 18). Resolução - RDC nº 344, de 13 de dezembro de 2002. Diário Oficial [da] República Federativa do Brasil.

Chang, Y. K., Hashimoto, J. M., Acioli-Moura, R., Martínez-Flores, H. E., \& Martínez-Bustos, F. (2001). Influence of extrusion condition on cassava starch and soybean protein concentrate blends. Acta Alimentaria, 30(2), 189-203.

Cozzolino, S. M. F., \& Cominetti, C. (2013). Bases bioquímicas e fisiológicas da nutrição: nas diferentes fases da vida, na saúde e na doença barueri. São Paulo: Manole.

Derringer, G. C., \& Suich, R. (1980). Simultaneous optimization of several response variables. Journal of Quality Technology, 12(4), 214-219. http://dx.doi.org/10.1080/00224065.1980.11980968.

Fellows, P. J. (2006). Tecnologia do processamento de alimentos: princípios e prática ( $2^{\text {nd }}$ ed.). Porto Alegre: Artmed.

Ferreira, R. E., Chang, Y. K., \& Steel, C. J. (2012). Influence of wheat bran addition and of thermoplastic extrusion process parameters on physical properties of corn-based expanded extruded snacks. Alimentos e Nutrição Araraquara, 22(4), 507-520.

Hirth, M., Leiter, A., Beck, S. M., \& Schuchmann, H. P. (2014). Effect of extrusion cooking process parameters on the retention of bilberry 
anthocyanins in starch based food. Journal of Food Engineering, 125, 139-146. http://dx.doi.org/10.1016/j.jfoodeng.2013.10.034.

Instituto Adolfo Lutz - IAL. (2008). Normas analíticas do Instituto Adolf Lutz: Métodos físicos e químicos para análise de alimentos (4th ed.). São Paulo: Métodos.

International Commission on Microbiological Specifications for Foods - ICMSF. (1983). Microrganisms in food ( $2^{\text {nd }}$ ed., 436 p.). Toronto: University of Toronto.

Leoro, M. G. V., Chang, Y. K., \& Steel, C. J. (2009). Efeito do teor de maracujá e da umidade e temperatura de extrusão no desenvolvimento de cereal matinal funcional orgânico. Brazilian Journal of Food Technology, 12(2), 145-154. http://dx.doi.org/10.4260/BJFT2009800900007.

Masuzaki, G., Schmiele, M., \& Chang, Y. K. (2015). Defatted chia flour as a fiber source in snacks: composition and technological characteristics. In Proceedings of tye 6th International Dietary Fibre Conference 2015. USA: Nutrition Science Corner.

Meng, X., Threinen, D., Hansen, M., \& Driedger, D. (2010). Effects of extrusion conditions on system parameters and physical properties of a chickpea flour-based snack. Food Research International, 43(2), 650-658. http://dx.doi.org/10.1016/j.foodres.2009.07.016.

Mercier, C., Linko, P., \& Harper, J. (1998). Extrusion cooking ( $2^{\text {nd }}$ ed.). St. Paul: American Association of Cereal Chemists.

Nair, K., Kharb, S., \& Thompkinson, D. K. (2010). Inulin dietary fiber with functional and health attributes - a review. Food Reviews International, 26(2), 189-203. http://dx.doi.org/10.1080/87559121003590664.

Nazário, P., Ferreira, S. A., \& Borges, E. E. L. (2017). Embryonic dormancy in seeds of Bactris gasipaes Kunth (peach-palm). Journal of Seed Science, 39(2), 106-113. http://dx.doi.org/10.1590/2317$1545 \mathrm{v} 39 \mathrm{n} 2163507$.
Oliveira, A. M. \& Marinho, H. A. (2010). Desenvolvimento de panetone à Base de Farinha de pupunha (Bactris gasipaes Kunth). Revista de Alimentos e Nutição, 21(4), 595-605.

Oliveira, L. C., Schmiele, M., \& Steel, C. J. (2015). Development of whole grain wheat flour extruded cereal and process impacts on color, expansion, and dry and bowl-life texture. LebensmittelWissenschaft + Technologie, 75, 261-270. http://dx.doi.org/10.1016/j. lwt.2016.08.064.

Onwulata, C. I., Konstance, R. P., Smith, P. W., \& Holsinger, V. H. (2001). Coextrusion of dietary fiber and milk proteins in expanded corn products. Lebensmittel Wissenschaft und Technologie (Zurich), 34(7), 424-429. http://dx.doi.org/10.1006/fstl.2000.0742.

Potter, R., Stojceska, V., \& Plunkett, A. (2013). The use of fruit powders in extruded snacks suitable for children's diets. LebensmittelWissenschaft + Technologie, 51(2), 537-544. http://dx.doi.org/10.1016/j. lwt.2012.11.015.

Silva, E. P., Abreu, W. C., Gonçalves, O. A., Damiani, C., \& Vilas Boas, E. V. (2017). Characterization of chemical and mineral composition of marolo (Annona crassiflora Mart) during physiological development. Food Science and Technology (Campinas), 37(1), 13-18. http://dx.doi. org/10.1590/1678-457x.0107.

Tavares, B. O., Silva, E. P., Silva, V. S. N., Soares, M. S. Jr, Ida, E. I., \& Damiani, C. (2016). Stability of gluten free sweet biscuit elaborated with rice bran, broken rice and okara. Food Science and Technology, 36(2), 296-303. http://dx.doi.org/10.1590/1678-457X.0083.

Wang, P., Fu, Y., Wang, L., Saleh, A. S., Cao, H., \& Xiao, Z. (2017). Effect of enrichment with stabilized rice bran and extrusion process on gelatinization and retrogradation properties of rice starch. Starch Staerke, 69(7-8), 1600201. http://dx.doi.org/10.1002/star.201600201. 